\title{
Having the cake and eating it too: the benefits of decoupling Australia's trade governance in Europe after Brexit and beyond
}

\author{
DAVID TREISMAN \\ Monash University, Australia \\ david.treisman@monash.edu \\ GIOVANNI DI LIETO \\ Monash University, Australia \\ giovanni.dilieto@monash.edu
}

\begin{abstract}
The process towards Brexit will impact on the entire global trading system and significantly influence the global value chains that rely on ease of trade and investment within a single European market. In light of this process, Australia with its high levels of international economic integration and interdependency of trade and investment to and from the European region, now faces a stark challenge in forging an economic position that best suits its national interests. This paper analyses the possible implications of Brexit on Australia's economic governance position, with specific regard to the global value chains that rely on ease of trade and investments in the European single market. The exploration relies on empirical analysis that distinguishes between and disaggregates data on Australian trade and investment with the UK and the rest of the European Union. This analysis indicates that it is in Australia's best interest is to prioritise a preferential partnership with the EU over a new free trade agreement with the UK. However, in order to maximise Australia's position, the paper argues that, under the present political climate and technical difficulties, a multi-pronged and decoupled approach of concerted unilateralism with the UK and preferential bilateralism with the EU is best placed to enhance Australia's geo-economic role in Europe in the post-Brexit era.
\end{abstract}

Keywords: Brexit, Australia-UK trade relationship, Australian trade policy in Europe.

\section{Introduction}

The 2016 United Kingdom European Union Membership Referendum was a watershed moment in contemporary global trade and investment. The United Kingdom (UK), the fifth largest economy in the world (WEF, 2017), traditionally a stalwart for global free trade and a gateway for international trade and investment to and from the European region firmly announced through the referendum its intention to change the structures that govern its international trade and investment.

These changes would inevitably impact on the entire global trading system and significantly influence the global value chains that rely on ease of trade and investments within a single European market. The stage has been set for trading 
partners to reconcile legal text with regime effectiveness and address how contemporary forces of globalisation are shaping the relative balance of influence (Scott, 2004; Bisley, 2007). One such case in point is that of Australia, a small openeconomy, with high levels of international economic integration and interdependency of trade and investment to and from the European region which, as a result, now faces a stark challenge in forging an economic position that best suits its national interests.

Accordingly, this paper analyses the possible implications of Brexit on Australia's economic governance position, with specific regard to the global value chains that rely on ease of trade and investment in the European single market. The exploration relies on empirical analysis that distinguishes between and disaggregates data on Australian trade and investment with the UK and the rest of the European Union. Fundamental to this exploration is the consideration of the implications of the UK's exit from the EU's customs union and financial market for third countries such as Australia. Such an exit is commonly referred to as a 'hard Brexit', as opposed to a soft Brexit whereby the UK keeps "close ties with the EU, possibly through some form of membership of the European Union single market” (BBC, 2017).

On this basis, the analysis indicates that, based on the market complementarity and financial exposure with the UK and the EU (minus the UK), Australia's best interest is to prioritise a preferential partnership with the EU over a new free trade agreement with the UK. However, in order to maximise Australia's position, and so to speak have the cake and eat it too, the paper argues that, under the present political climate and technical difficulties, a multi-pronged and decoupled approach of concerted unilateralism with the UK and preferential bilateralism with the EU is best placed to enhance Australia's geo-economic role in Europe in the post-Brexit era.

The paper proceeds as follows: the next section explores relevant data and literature on Australia's economic relations with the EU and the UK. Following there is an empirical analysis of Australia's trade and investment relationship with the UK and the EU (minus the UK). The concluding section provides a policy analysis which is based on the empirical findings as to the implications of Brexit and the potential way forward for Australia in the post-Brexit era.

\section{Australian-EU and UK Relations: Brexit and Beyond}

Australia's positioning in terms of its trade and investment relationships with the EU and UK from Brexit and beyond is being shaped by forces and systems that underpin global and regional trade, its foreign economic relations and the potential it has in influencing global value chains.

Governance of contemporary international trade and investment has evolved from the drive for multilateralism. This is the case in point made by Baldwin (2016), who investigated the implications of the stalled Doha Round of negotiations under the WTO. Ongoing trade and investment together with the stalled drive toward multilateralism has, argues Baldwin (2016), given rise to a two-pillar governance structure: the first made up of centralised WTO rules aimed at governing traditional trade, and the second pillar is a new set of decentralised rules aimed at governing international production networks that often overlap and are inconsistent with megaregional agreements. 
The importance of the changes to governance arising from the meeting point between multilateralism and actual economic activity is a consistent feature of contemporary international trade and investment. These meeting points appear to be strongly correlated with intersection between regional trading arrangements and global trade and investment. These contentions are supported by Poon's (1997) investigation of observed regional trading coalescence in the flows of intra- and inter firm trade by multinational corporations. Poon (1997) found that regional trading coalescence stems from greater trade within trading bloc countries which, in itself, simultaneously increases the propensity for extra-regional trade and underpins global value chains.

A similar conclusion was made by Kohl and Brouwer's (2014) study into the economic geography of international trade over the second half of the $20^{\text {th }}$ century, in which they demonstrate that, even if approached from a condition of globalisation, proximity and economic integration agreements are determinants of the persistence of region-based trading blocs. However, centrality of regions has greater bearing on trade then that of investment. This point was highlighted in Poon et al's (2000) analysis of the division of economic regions in which they mapped the intensity of trade and foreign direct investment between countries and found that trade is organised around fewer world regions while investment does not conform to any bloc-like formation.

Within the context of these forces and systems that shape global and regional trade, the literature on Australia's contemporary foreign economic relations especially with regard to the EU and the UK can be better explored. Until as recent as 2016, Australia's foreign economic policy with the EU was well described by Kenyon \& Kunkel (2005) in their study of the relationship between the EU and Australia at the World Trade Organisation (WTO): Australia and the EU have increasingly shared interests in the liberalisation of trade of industrial products and services, strengthening WTO processes and domestic regulation. However, historical conflict over agricultural policy still dominated the relationship in multilateral trade negotiations.

However, Rimmer (2016) provides a more contemporary view of Australian foreign economic policy through his analysis of Australia's choice of diplomatic forums. Rimmer (2016) argues that Australia's diplomatic investments are increasingly driven by its desire to reduce the dominance of the complex interdependency it maintains with the Asia-Pacific region's two great powers (China and USA). It is on this basis that Rimmer (2016) contends that contemporary Australian diplomatic investments have increasingly been directed toward regional architecture, mini-lateral dialogues, foreign minister groupings, pluri-lateral processes and bilateral free trade agreements.

Murray and Benvenuti's (2014) critical examination of the evolution and status of Australia-EU relations echo these contentions. Murray and Benvenuti (2014) indeed highlight Australia's expansion of its narrow formulation of national interests to include regional and multilateral agendas that are shared with that of the EU. In this regard, Murray and Benvenuti (2014) argue that several factors have led to this expansion: notably the changing relationship with the UK as a trade interlocutor/market and the diminution of the importance of agricultural policy.

However, others argue that different drivers have determined contemporary Australian-EU relations. Mckenzie's (2016) analysis of wine trade negotiations between Australia and the EU presents a picture of EU institutional inflexibility leading to disproportionate market access concessions for Australia: the inflexibility created 
by the EU's political institutions over previous negotiations with Australia, diminished the EU's negotiating capability and led to an underestimation of the impact of free market access for Australian wine exports to the EU. Hussey and Kenyon's (2011) investigation, on the other hand, emphasises the importance of domestic regulations as impediments to trade and investment relations between Australia and the EU in which they explain the changing relationship being due to the EU moving away from attempts to achieve regulatory harmonisation to a position of mutual recognition of heterogeneous regulations.

Australia's foreign economic relations are of growing importance for trade and investment especially in terms of the interaction between the State and the market, specifically the role played by economic governance and global value chains. Sahu's (2016) empirical investigation of global value chains supports this contention. Sahu (2016) evaluated the contribution of strategic policy reforms and governance in terms of value added to Malaysia's trade. Sahu (2016) demonstrated that strategic policy reforms and governance maintain a significant relationship with trade in value added and that government plays a significant role in domestic value added exports.

Sahu's (2016) findings are echoed in the 2010 Australian Government's Productivity Commission Report on Bilateral and Regional Free Trade Agreements [BRTAs], which provide two significant conclusions. Firstly, preferential trade and investment arrangements "can significantly increase trade flows between partner countries, although some of this increase is typically offset by trade diversion from other countries". Secondly, that increased trade flows per se produce only a modest improvement in national income and commercial benefits, because "the main factors that influence decisions to do business in other countries lie outside the scope of BRTAs".

Villalta Puig (2012) echoes and links the finding of Sahu (2016) and of the 2010 Australian Productivity Commission Report with particular reference to trade and investment relationship between the EU and Australia. Villalta Puig (2012) outlines two causes behind the absence of a preferential trading agreement (PTA) between the EU and Australia: 1) the dominance of great powers in the Asia-Pacific region, and 2) historical tensions over the Common Agricultural Policy (CAP). However, Villalta Puig (2012) recognises the economic importance of the EU for Australia and argues that the difficulties surrounding agricultural policies could be practically sidestepped if PTA efforts between Australia and the EU were directed toward an agreement on trade in services and trade-related investment measures.

However, the importance of Australia's foreign economic relations with the EU for trade and investment remains an underexplored topic in the literature, especially in terms of the role played by governance and global value chains. This paper addresses this deficiency by critically approaching Australia's foreign economic relations with the EU (excluding the UK) and with the UK (as an individual partner) on the basis of the significant conclusions of the 2010 Australian Productivity Commission Report.

The centrality of the UK in Australia's economic relations with the EU is reflected in the market activity between the trading partners. In fact, in 2015 the UK ranked as Australia's $8^{\text {th }}$ largest merchandise export destination $\left(2.9 \%\right.$ of total) and its $10^{\text {th }}$ largest source of merchandise imports (2.8\% of total). Similarly, the UK ranked as Australia's 3 rd largest export destination for services (7.2\% of total) and its $2^{\text {nd }}$ largest 
source of imported services (9.4\%). Table 1 below also shows the amount of foreign direct investment (FDI) stocks as of 2015, with a combined total of approximately A\$ 850 million.

Whereas, the EU in the 2015-2016 financial year accounted for $6.7 \%$ of total merchandise exports, $18 \%$ of total merchandise imports, $15.3 \%$ of total export of services and $25.7 \%$ of total imports of services, as tallied by the DFAT European Union (EU) Fact Sheet.

However, the primacy of the UK in Australia's economic relations with the EU is further demonstrated in table 1 above. The UK alone contributes between 15 to $47 \%$ to the composition of Australia's trade relationship with the EU as a whole.

Thus, in order to gauge the possible implications for Australia's trade and investment relationships with the UK and the EU, the following sections assess key market trends in relation to 1) trade in goods; 2) trade in services; 3) capital investments; and 4) labour movement.

The aggregated analysis of these four areas assess Australia's trade and investment relationship with both the UK as an individual economic partner and the EU as a single market without the UK, hereafter referred to as EUBrex.

Table 1: Snapshot of Australian economic relations with the UK in 2015

\begin{tabular}{l|c}
\hline GOODS & $\underline{\mathbf{U K}}$ \\
Merchandise Exports (A\$ millions) & 7158 \\
Merchandise Exports (Rank) & 8 \\
Merchandise Exports (\% of Total) & 2.9 \\
Merchandise Exports (\% of EU) & 4.1 \\
Merchandise Imports (A\$ millions) & 7584 \\
Merchandise Imports (Rank) & 10 \\
Merchandise Imports (\% of Total) & 2.8 \\
Merchandise Imports (\% of EU) & 15.5 \\
\hline SERVICES & 4911 \\
Commercial Services Exports (A\$ millions) & 3 \\
Commercial Services Exports (Rank) & 7.2 \\
Commercial Services Exports (\% of Total) & 47 \\
Commercial Services Exports (\% of EU) & 7316 \\
Commercial Services Imports (A\$ millions) & 2 \\
Commercial Services Imports (Rank) & 9.4 \\
Commercial Services Imports (\% of Total) & 36.7 \\
Commercial Services Imports (\% of EU) & \\
\hline FOREIGN DIRECT INVESTMENT & 499930 \\
FDI Inward Stock to Australia (A\$ millions) & 50.5 \\
FDI Inward Stock to Australia (\% of EU) & 353204 \\
FDI Outward Stock from Australia (A\$ millions) & 59.9 \\
FDI Outward Stock from Australia (\% of EU) & \\
Sources: Australian Department of Foreign Affairs and Trade Fact Sheets and authors' \\
calculations & \\
\hline & \\
\hline
\end{tabular}

\section{Empirical Analysis}

\section{A. Trade In Goods}


Four indicators of trade in goods with the UK and EUBrex were compiled for the period from 2007 to 2015, namely: a) export share; b) import share; c) export similarity; and d) trade complementarity.

Export and import share indicates the importance of a trading partner in terms of worldwide Australian exports and imports. Export and import shares are represented as a percentage of total Australian exports and imports and provide a means to track the relative importance of a trading partner over time. In terms of export share, as indicated in figure 1, the importance of the UK as an export destination has on the whole been in the decline since 2007 , peaking in 2009 at $4.6 \%$ and falling to $1.48 \%$ by 2015 .

A similar downward trend is identified for the EUBrex as trading partner with general downward trend in export share from a high of $7.2 \%$ in 2007 to $3.49 \%$ in 2015 . The UK and EUBrex do not appear to be sizeable individual markets for Australian exports contributing less than 10\% of total Australian exports. Overall, with the exception of 2009, the EUBrex has consistently exceeded the UK as an export destination.

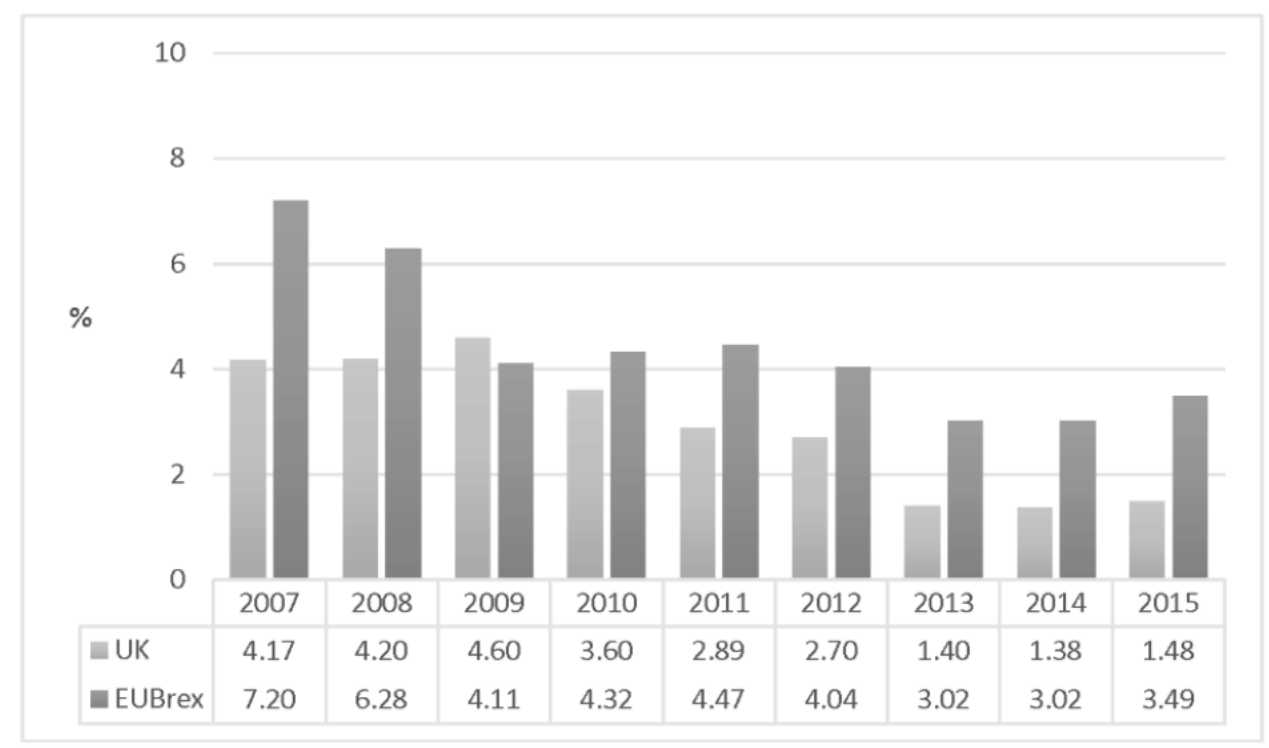

Notes: 1. Geometric Mean (UK) $=2.65 \%$; 2. Geometric Mean $($ EUBrex $)=4.26 \%$

Source: UNCTAD Stat Database and authors' calculations

Figure 1: Export share of Australian goods to the world (2007-15)

As figure 2 indicates, a similar pattern is observed with import share of the UK and EUBrex declining over time. The UK import share has been below 5\% over the period of observation, whereas the EUBrex has been consistently above $14.5 \%$ over the same period. In contrast to the exports, the EUBrex should be regarded as a major source of Australian imports.

Consequently, export and import shares of the UK and EUBrex with Australia permits further investigation as to export similarity and trade complementarity between each trading partner. 


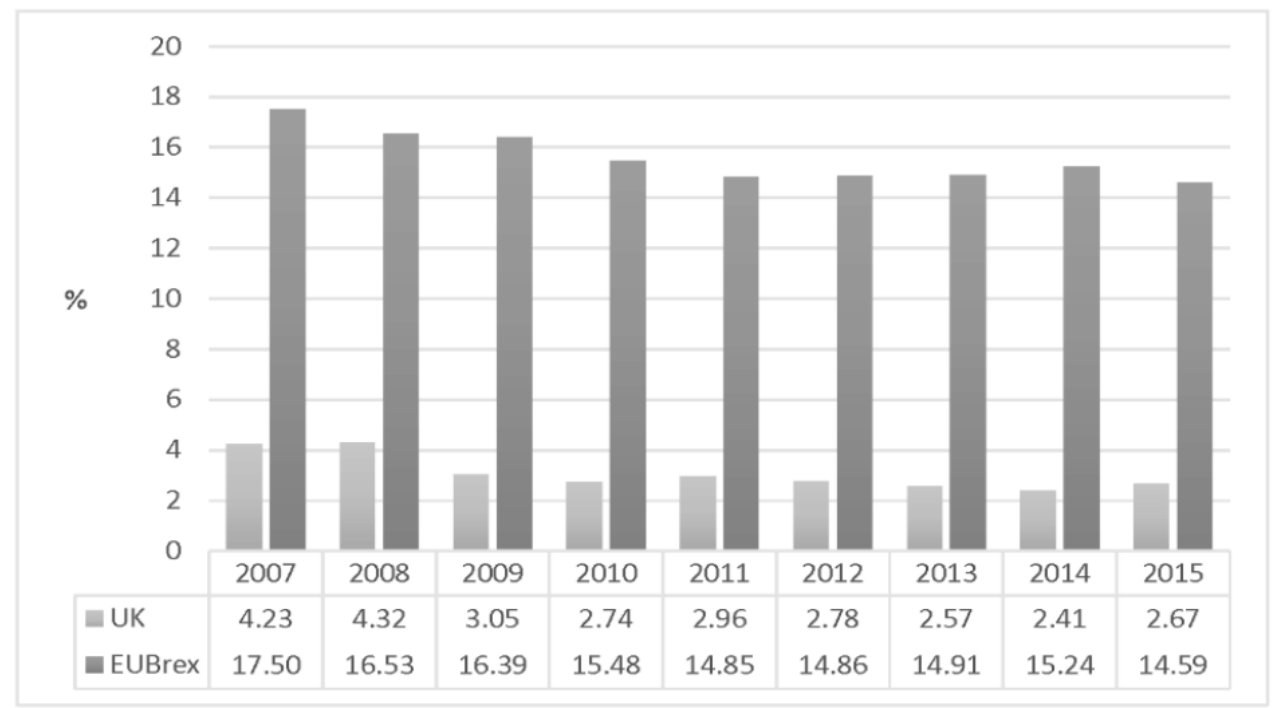

Notes: 1 . Geometric Mean (UK) $=3.02 \% ; 2$. Geometric Mean (EUBrex) $=15.57 \%$ Source: UNCTAD Stat Database and authors' calculations

Figure 2: Import share of Australian goods to the world (2007-15)

Export similarity measures the extent of overlapping exports of trading pairs and is used to gauge competition for worldwide export markets between trading partners - i.e. the higher the percentage of export similarity, the higher the degree of competition.

As figure 3 shows, export similarity between Australia and the UK has fluctuated since 2007 in a general downwards trend, averaging $45.99 \%$.

In comparison, the export similarity between Australia and the EUBrex has followed a similar pattern of fluctuation and downwards trend in since 2007, but has averaged $40.86 \%$.

In both cases, the UK and EUBrex demonstrate a sizeable (above 40\%) match in global export markets.

This in itself is not too surprising a feature, as all three trading partners are major global trading nations.

However, the persistent level of competition for global markets between Australia and the UK, and between Australia and the EUBrex is likely to hinder future trade negotiations, as it will be difficult to prove significant commercial advances from preferential bilateral agreements.

Given the higher degree of Australia's trade competition with the UK than with the EUBrex, this concern is expected to play a larger feature in future negotiations with the UK. 


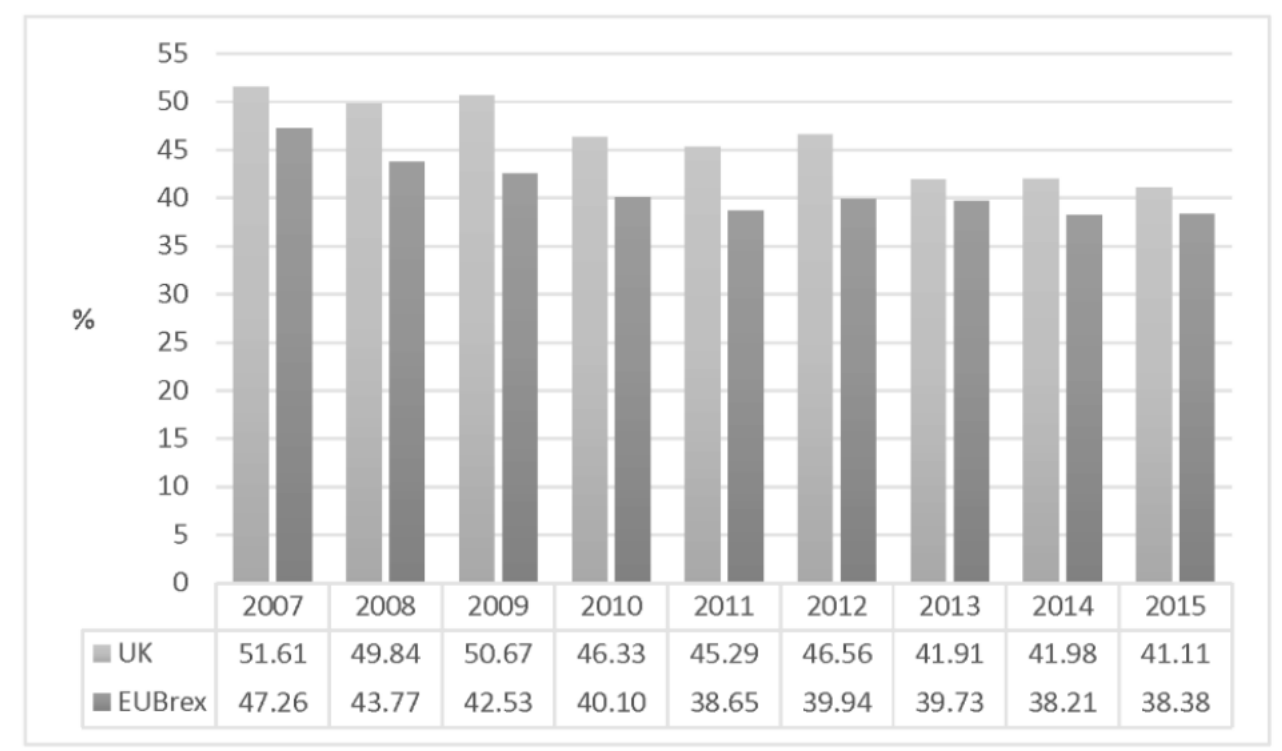

Notes: 1 . Geometric Mean (UK) $=45.99 \% ; 2$. Geometric Mean (EUBrex) $=40.86 \%$ Source: UNCTAD Stat Database and authors' calculations

Figure 3: Export similarity: Australia-UK and Australia-EUBrex (2007-15)

In contrast to export similarity, trade complementarity measures the overlap from one import market to the export market of another across different sectors and is thus seen as an indicator of likelihood for establishing a favourable trading arrangement i.e. the higher the percentage of overlaps, the higher the degree of complementarity. However, trade complementarity is an asymmetric indicator as it measures the overlap from one import market to the export market of another. This implies that trade complementarity indicators will and do differ between the same pair of trading partners depending on which import and export market is identified for analysis and by extension who benefits in terms of the consumers of imports or the producers of exports.

From the perspective of Australia and the UK, figure 4 below shows that the Australian imports are well served by the UK exports (more than a 78\% overlap), however the UK imports are less well served by Australian exports (no more than a $53.87 \%$ overlap). 


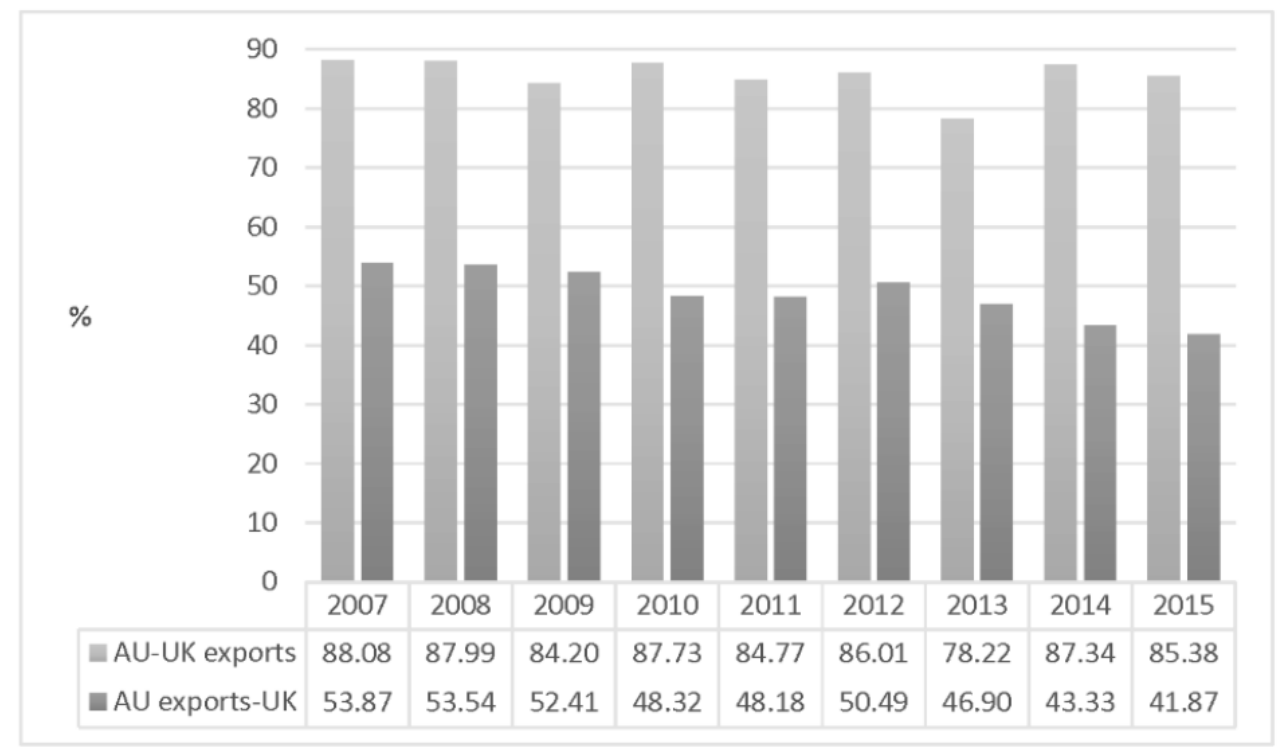

Notes: 1 . Geometric Mean (AU-UK exports) $=85.47 \% ; 2$. Geometric Mean (AU exports-UK) $=48.60 \%$ Source: UNCTAD Stat Database and authors' calculations

Figure 4: Complementarity of trade in goods: Australia-UK (2007-15)

The significant differences in trade complementarity between Australia and the UK imply that it will be difficult to establish mutually beneficial trade arrangements.

In particular, such differential in trade complementarity between Australia and the UK shows that the UK exporters are poised to benefit significantly more than Australian exporters from a preferential bilateral FTA.

In comparison with the UK, as indicated in figure 5 below on trade complementarity between Australia and the EUBrex, Australian imports are better served by the EUBrex exports (more than an 85\% overlap), and the EUBrex imports are better served by Australian exports (no more than a 59.12\% overlap).

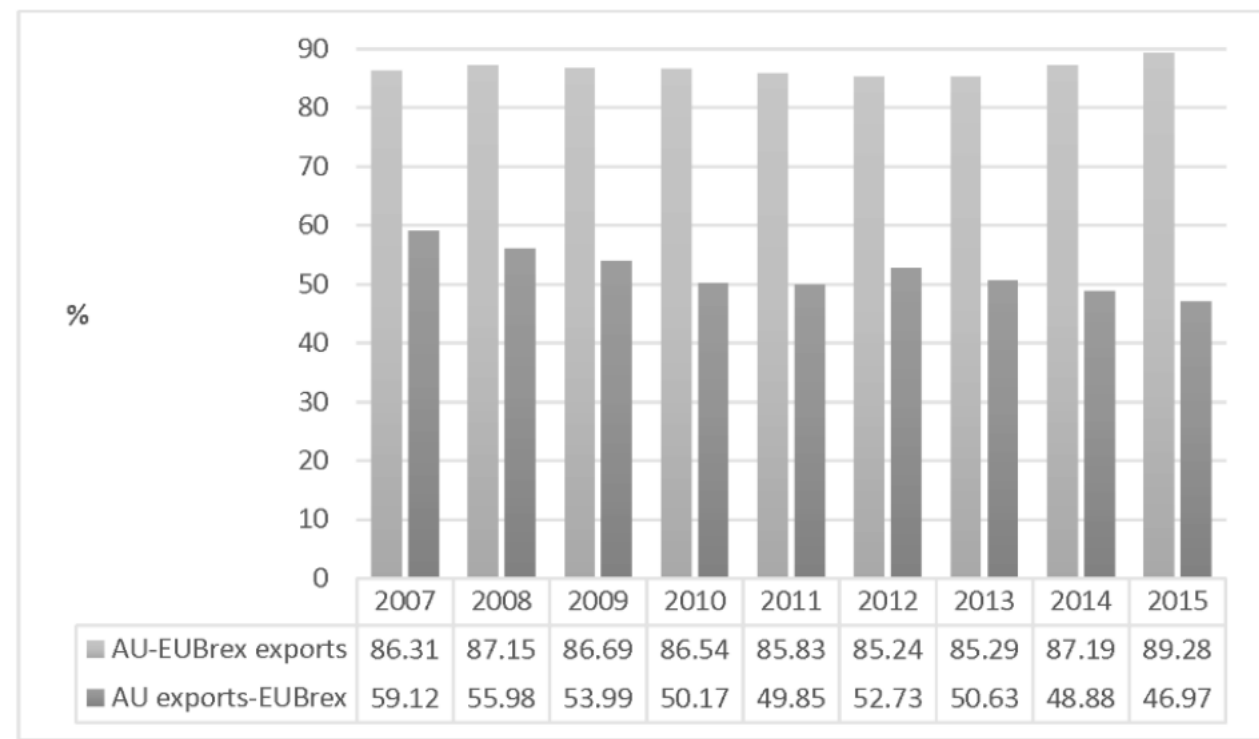

Notes: 1. Geometric Mean (AU-EUBrex exports) $=86.60 \% ; 2$. Geometric Mean (AU exports-EUBrex) $=$ $51.92 \%$

Source: UNCTAD Stat Database and authors' calculations

Figure 5: Complementarity of trade in goods: Australia-EUBrex (2007-15) 
Nonetheless, sizeable differences in trade complementarity between Australia and the EUBrex imply that it will still be difficult to establish mutually beneficial trade arrangements, as Australian exporters would gain less than the EUBrex exporters, however less so than in comparable arrangements with the UK.

At this point, it becomes clear that for Australia a preferential bilateral FTA with the EUBrex is more desirable than one with the UK, and the cross-check of trade complementarity with trade competition further confirms this reasoning.

In fact, the likely benefits of potential arrangements for Australian exports so far has been understood to be a relative gain.

However, little is indicated as to whether the gain achieved for Australian consumers of imports will be achieved at the expense of the Australian producers of exports.

To assess whether potential arrangements are likely to be beneficial to Australian producers of exports, it is necessary to compare measures of complementarity (with exports from Australia) to those of export competition.

The logic of this approach is that the current gains achieved by Australian producers of exports occur under the constraint of competition, and that cooperation reduces market rivalry.

Therefore, trade complementarity must exceed trade competition if producers of exports are to gain from trade cooperation.

Figure 6 shows that gains from cooperation for Australian producers of exports would have been positive over the period 2007 to 2015 if potential trade arrangements with the UK and EUBrex had been in place.

However, the gains for Australian producers of exports would have been considerably greater from an arrangement with the EUBrex than from a comparable cooperation with the UK.

According to this analysis, entering into preferential trading agreements with the UK and EUBrex will be, on aggregate, beneficial for Australia.

To understand which sectors will be winners or losers from such arrangements needs further investigation.

For this very reason, given the political uncertainty of post-Brexit negotiations between the UK and EU, Australia's economic diplomacy should be mindful of sequencing its own negotiations in ways that maximise trade complementarity and limit trade competition with the various European partners. 


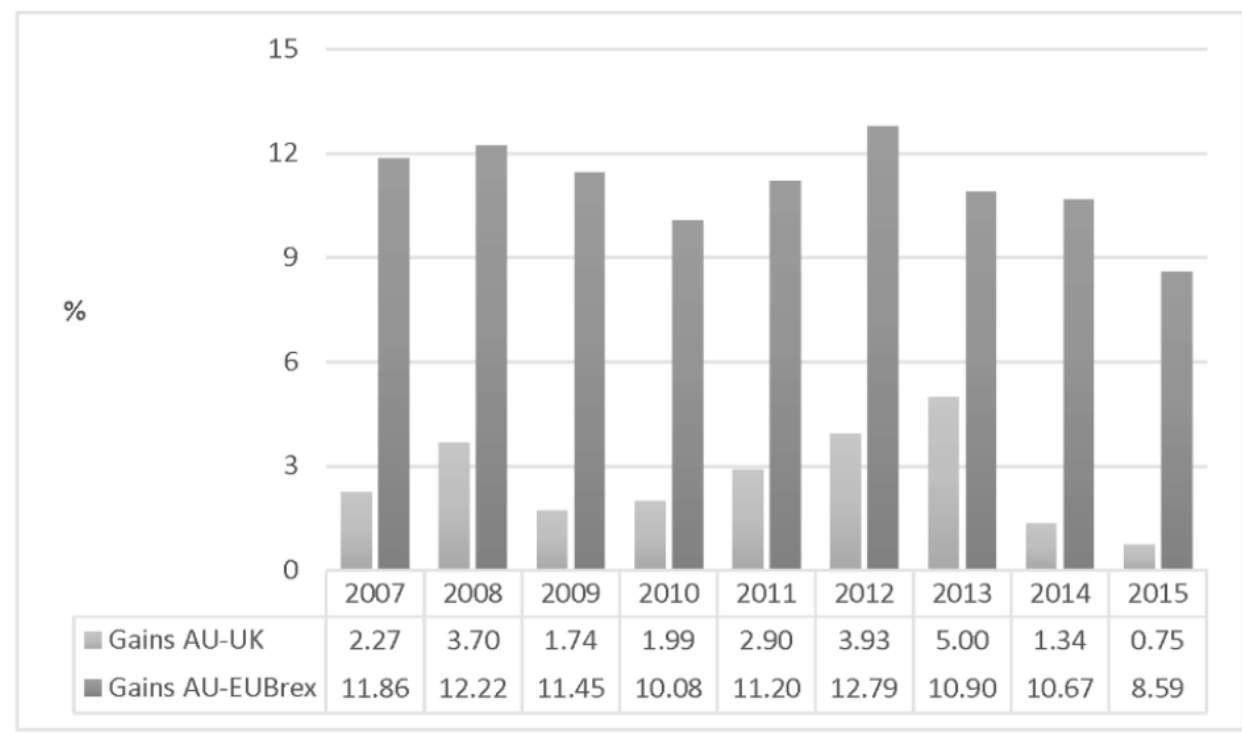

Notes: 1. Geometric Mean (Gains AU-UK) $=2.28 \%$; 2. Geometric Mean (Gains AU-EUBrex) $=11.02 \%$;

3. Gains in exports are defined as the difference between complimentarity (AU exports) and export similarity with the trading partner

Source: UNCTAD Stat Database and authors' calculations

Figure 6: Potential AU gains in export cooperation: AU-UK and AU-EUBrex (2007-15)

Consequently, an area for further consideration is to what extent a hard Brexit will reduce the value of Australia's exports and imports due to the disruption of the global value chains that rely on ease of trade between the UK and EUBrex.

In order to make such an assessment, the calculation for selected years captures the dollar value add of manufactured goods from Australia or the EUBrex passing through the UK, and with the final destination of either the EUBrex or Australian markets refer to table 2 below.

Although further analysis is still needed, the data from the OECD EBOPS 2010/TiVA Database on the intermediate and final trade in manufactured goods indicate two potential outcomes under a hard Brexit:

a) On average up to US $\$ 0.47$ billion of value per annum of Australian exports can be disrupted, thus potentially reducing Australia's industrial output; and

b) On average up to US $\$ 1.37$ billion value of imports to Australia per annum could become more expensive, thus increasing the cost of domestic production and consumption. 
Table 2: Maximum potential reduction of Australian manufactured goods Exports and Imports: Global Value Chains under a "Hard" Brexit (2010 and 2015)

\begin{tabular}{|c|c|c|c|}
\hline \multicolumn{4}{|c|}{ AU Exports } \\
\hline Year & $\begin{array}{c}\text { AU Domestic } \\
\text { Value Added } \\
\text { by Gross } \\
\text { Exports with } \\
\text { UK } \\
\text { US } \$ \text { mil.) }\end{array}$ & $\begin{array}{l}\text { EU share of } \\
\text { UK Domestic } \\
\text { Value Added } \\
\text { (\% of Total) }\end{array}$ & $\begin{array}{c}\text { Max. } \\
\text { Reduction AU } \\
\text { Domestic } \\
\text { Value Added } \\
\text { (US\$ mil.) }\end{array}$ \\
\hline 2008 & 1317.34 & $43.90 \%$ & 578.31 \\
\hline 2009 & 908.87 & $43.67 \%$ & 396.90 \\
\hline 2010 & 1062.01 & $40.82 \%$ & 433.51 \\
\hline 2011 & 1124.65 & $40.87 \%$ & 459.64 \\
\hline Average & 1103.22 & $42.29 \%$ & 467.09 \\
\hline
\end{tabular}

\begin{tabular}{|c|c|c|c|}
\hline \multicolumn{4}{|c|}{ AU Imports } \\
\hline Year & $\begin{array}{c}\text { AU Foreign } \\
\text { Value Added } \\
\text { by Gross } \\
\text { Exports with } \\
\text { UK } \\
\text { US\$ mil.) }\end{array}$ & $\begin{array}{l}\text { EU share of } \\
\text { UK Foreign } \\
\text { Value Added } \\
\text { \% of Total) }\end{array}$ & $\begin{array}{c}\text { Max. } \\
\text { Reduction AU } \\
\text { Foreign } \\
\text { Value Added } \\
\text { (US\$ mil.) }\end{array}$ \\
\hline 2008 & 2773.03 & $51.42 \%$ & 1425.89 \\
\hline 2009 & 2230.85 & $48.81 \%$ & 1088.88 \\
\hline 2010 & 2522.01 & $48.11 \%$ & 1213.34 \\
\hline 2011 & 3514.57 & $49.31 \%$ & 1733.03 \\
\hline Average & 2760.12 & $49.40 \%$ & 1365.29 \\
\hline
\end{tabular}

Source: OECD Stat EBOPS 2010/TiVA Database and authors' calculations

\section{B. Trade In Services}

Sectoral level data on trade in services is traditionally inconsistent or incomplete. Given these limitations, two indicators of trade in services with the UK and EUBrex were compiled for the period of 2007 to 2015, namely: a) export share; and b) import share. As for trade in goods, export and import shares indicate the importance of a trading partner in terms of worldwide Australian exports and imports. Export and import shares are represented as a percentage of the total Australian exports and imports, and provide a means to track the relative importance of a trading partner over time.

In terms of export share in services, figure 7 shows that the importance of the UK as an export destination declined considerably from 2007 to 2009 before settling to approximately $7.7 \%$ thereafter.

A much milder decline in EUBrex as a destination for Australian services was experienced during 2007-2009, but it has maintained a more stable average of $9.06 \%$ over the entire period under analysis.

Albeit similar in scale, the UK and EUBrex do not appear to be sizeable individual markets for Australian services exports, contributing less than 10\% of total Australian exports in this regard.

Nonetheless, the stability of exports to EUBrex, especially post global financial crisis, points toward the EUBrex being a more robust market for Australian services exports after Brexit.

Accordingly, the EUBrex as a market for export of Australian services is likely to remain a more significant partner than the UK. 


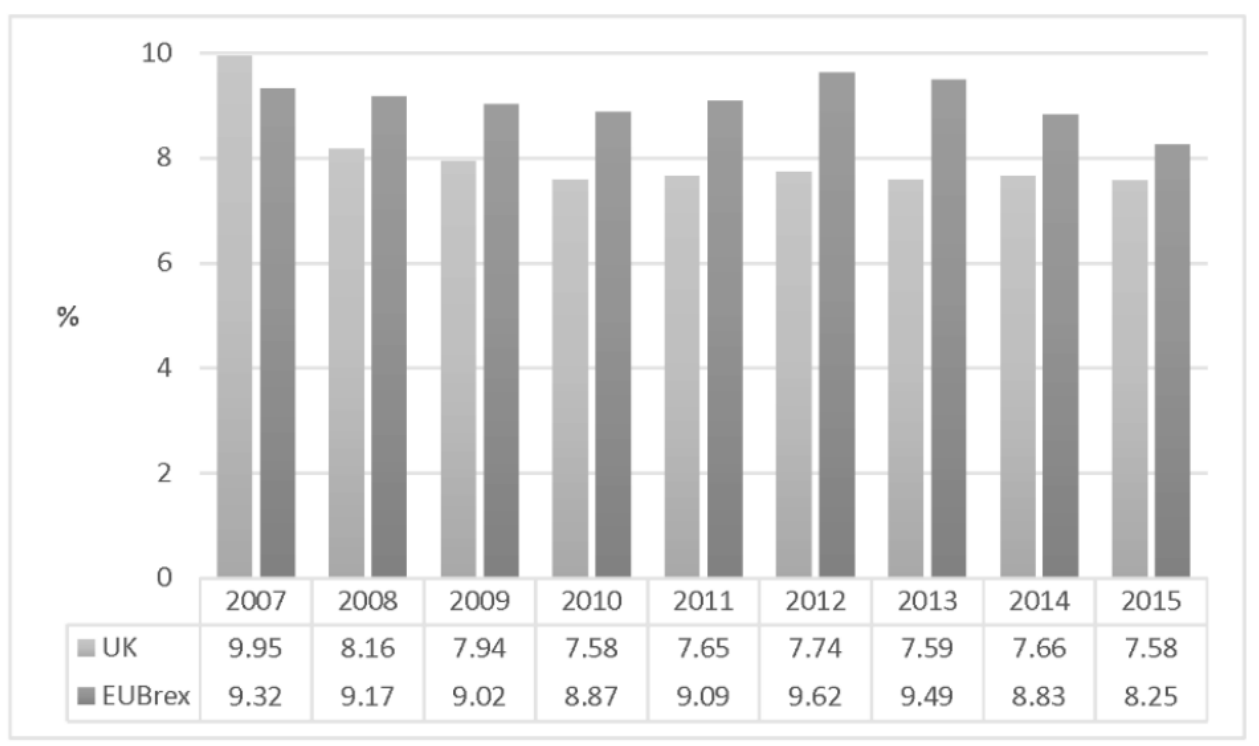

Notes: 1 . Geometric Mean (UK) $=7.95 \% ; 2$. Geometric Mean $($ EUBrex $)=9.06 \%$

Source: OECD EBOPS 2010 Database and authors' calculations

Figure 7: Export share of Australian services to the world (2007-15)

Similarly to the export share, figure 8 below shows that overall rising fluctuations have occurred in the past decade with the import share of the UK and EUBrex.

The UK import share has demonstrated less variability than the EUBrex, and has been below $10 \%$ over the period of observation.

This pattern contrasts with the EUBrex, whose import share of Australian services has greater variability and has been consistently above $13 \%$ over the same period.

With the average import share above 10\%, the EUBrex should be regarded as a major source of Australian services imports.

Given the long-established difference in magnitudes between services imports from the UK and EUBrex, the latter is likely to maintain this primary import position also post Brexit. 


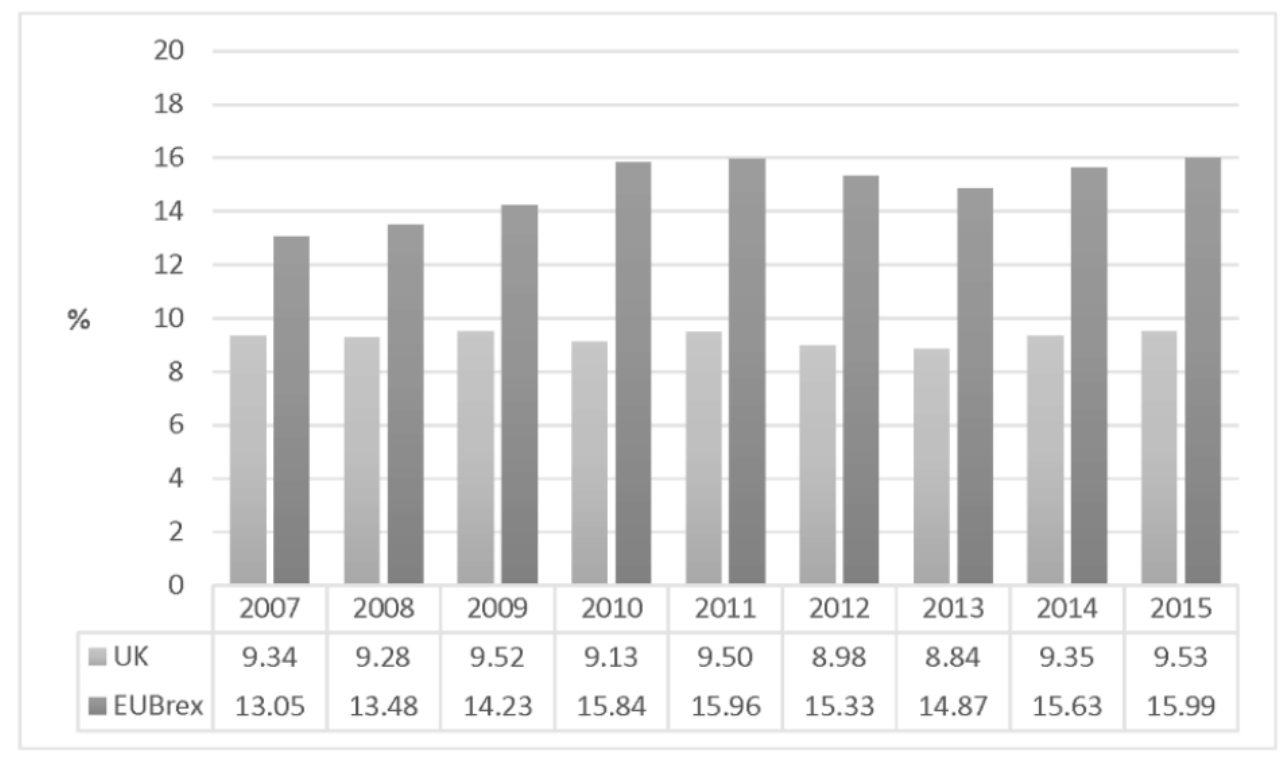

Notes: 1 . Geometric Mean (UK) $=9.27 \% ; 2$. Geometric Mean (EUBrex) $=14.89 \%$ Source: OECD EBOPS 2010 Database and authors' calculations

Figure 8: Import share of Australian services to the world (2007-15)

As was the case with the trade in goods, an area for further consideration is to what extent a hard Brexit will reduce the value of Australia's services exports and imports due to disruption of the global value chains that rely on ease of trade and investment between the UK and EUBrex.

In order to make such an assessment, the calculation for selected years captures the dollar value add of business services from Australia or EUBrex passing through the UK, and with the final destination of either EUBrex or Australian markets - see table 3 below.

Although further analysis is still needed, the data from the OECD EBOPS 2010/TiVA Database on the intermediate and final trade in business services indicate two potential outcomes under a hard Brexit:

a) On average up to US $\$ 1.47$ billion of value of Australian exports can be disrupted per annum, thus potentially reducing Australia's industrial output; and

b) On average up to US $\$ 3.36$ billion value of imports to Australia per annum could become more expensive, thus increasing the cost of domestic production and consumption. 
Table 3: Maximum potential reduction of Australian business services Exports and Imports: Global Value Chains under a "Hard" Brexit (2010 and 2015)

\begin{tabular}{|c|c|c|c|}
\hline \multicolumn{4}{|c|}{ AU Exports } \\
\hline & $\begin{array}{c}\text { AU Domestic } \\
\text { Value Added } \\
\text { by Gross } \\
\text { Exports with } \\
\text { UK } \\
\text { Year }\end{array}$ & $\begin{array}{c}\text { EU share of } \\
\text { UK Domestic } \\
\text { Value Added }\end{array}$ & $\begin{array}{c}\text { Max. } \\
\text { Reduction AU } \\
\text { Domestic } \\
\text { Value Added }\end{array}$ \\
2008 & 4068.79 & (\% of Total) & (US\$ mil.) \\
2010 & 2997.47 & $42.32 \%$ & 1721.91 \\
2011 & 3636.04 & $39.91 \%$ & 1263.43 \\
Average & 3687.99 & $39.56 \%$ & 1451.14 \\
\hline
\end{tabular}

\begin{tabular}{|c|c|c|c|}
\hline \multicolumn{4}{|c|}{ AU Imports } \\
\hline & $\begin{array}{c}\text { AU Foreign } \\
\text { Value Added } \\
\text { by Gross } \\
\text { Exports with } \\
\text { UK }\end{array}$ & $\begin{array}{l}\text { EU share of } \\
\text { UK Foreign } \\
\text { Value Added }\end{array}$ & $\begin{array}{c}\text { Max. } \\
\text { Reduction AU } \\
\text { Foreign } \\
\text { Value Added }\end{array}$ \\
\hline$\underline{\text { Year }}$ & (US\$ mil.) & $\%$ of Total) & (US\$ mil.) \\
\hline 2008 & 6728.20 & $52.11 \%$ & 3506.07 \\
\hline 2009 & 5724.79 & $51.09 \%$ & 2924.80 \\
\hline 2010 & 6537.05 & $48.85 \%$ & 3193.35 \\
\hline 2011 & 7768.05 & $48.88 \%$ & 3797.02 \\
\hline Average & 6689.52 & $50.21 \%$ & 3355.31 \\
\hline
\end{tabular}

Source: OECD Stat EBOPS 2010/TiVA Database and authors' calculations

\section{Capital Investments}

This section investigates capital investments through two channels: a) foreign direct investment (FDI); and b) portfolio investment (PI), with particular focus on the importance of both channels for Australian businesses.

In the context of this paper, FDI is initially assessed from the host country perspective in terms of the contribution of inflows from the source as percentage of global inflows since 2009.

Much like import share for trade in goods and services, the percentage contribution indicates the importance of a source nation for its host nation's total FDI inflows.

Accordingly, it is necessary to use stock variables, as these are believed to best reflect the activities of multinational corporations (MNCs) operating within the host nation in terms of the influence they have over industrial production and service provision relations.

Figure 9 below compares the UK and EUBrex FDI inflows in relation to Australia. Historically, FDI inflows from the UK and EUBrex have jointly contributed more than 21 percent of global FDI inflows to Australia.

Independent FDI inflows from the UK and EUBrex to Australia are similar in recent years, and have since 2009 averaged $11.59 \%$ and $12.73 \%$ respectively.

The pattern of FDI inflows from the UK appears to be more cyclical than that of the EUBrex, and FDI inflows from both sources have fluctuated over the period under investigation.

In most cases, FDI inflows from the UK and EUBrex are lower in recent years than at the beginning of the period under investigation. 


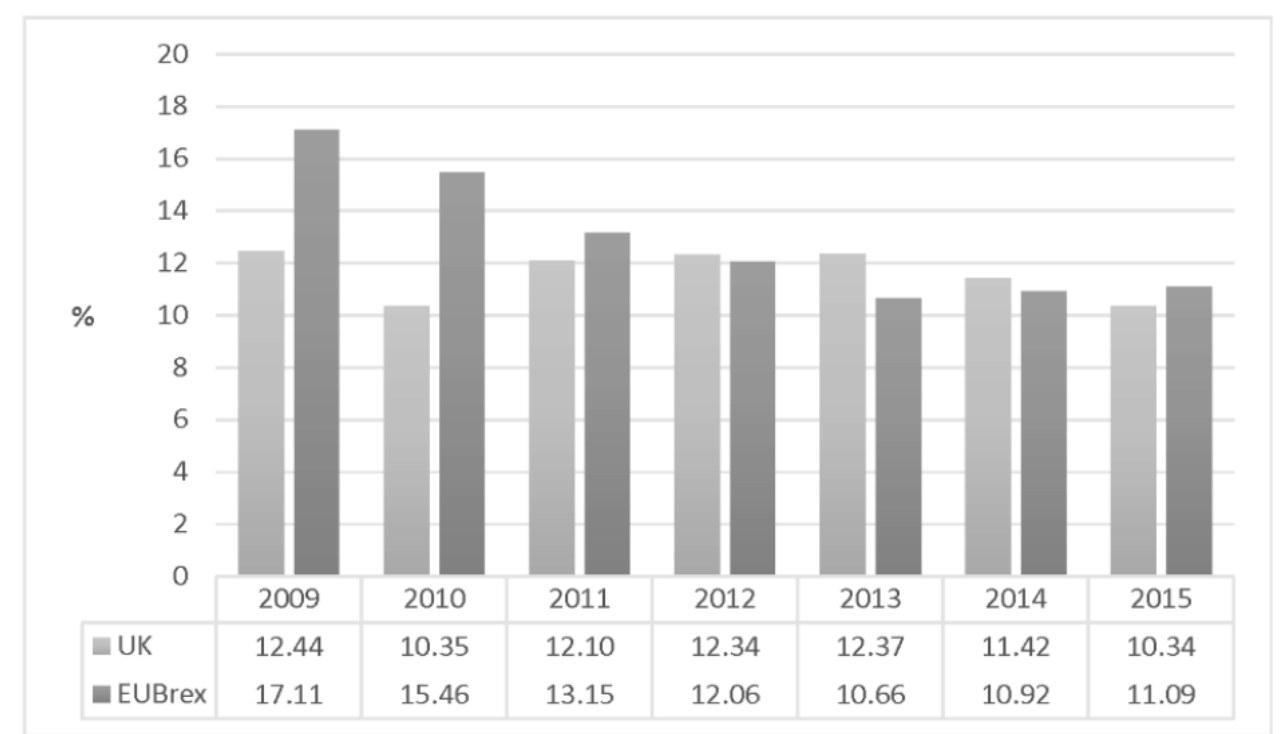

Notes: 1 . Geometric Mean $(\mathrm{UK})=11.59 \% ; 2$. Geometric Mean (EUBrex) $=12.73 \%$; 3. FDI stock values based on inward directional principle

Source: OECD Stat Database and authors' calculations

Figure 9: Contribution to Total FDI Stock in Australia (2009-15)

Even with these fluctuations, Australia continues to be a relatively stable market for the direct investments of the UK and EUBrex MNCs.

Jointly and separately, UK and EUBrex MNCs are indeed likely to maintain a sizeable influence on industrial production and service provision relations in Australia.

In contrast, within the constraints of limited data availability in the analysis of FDI inflows from Australia and the EUBrex, figure 10 below shows that, although Australian FDI to the UK has been increasing over the 2013-2015 period, Australian FDI inflows only average around $1.1 \%$ of global FDI inflows to the UK market.

The global FDI inflows in the UK market originating from the EUBrex are far greater, at an average of $46.53 \%$, albeit on a declining trend.

On this basis, it can be argued that Australian MNCs have little direct influence or leverage on industrial production and service provision relations in the UK. 


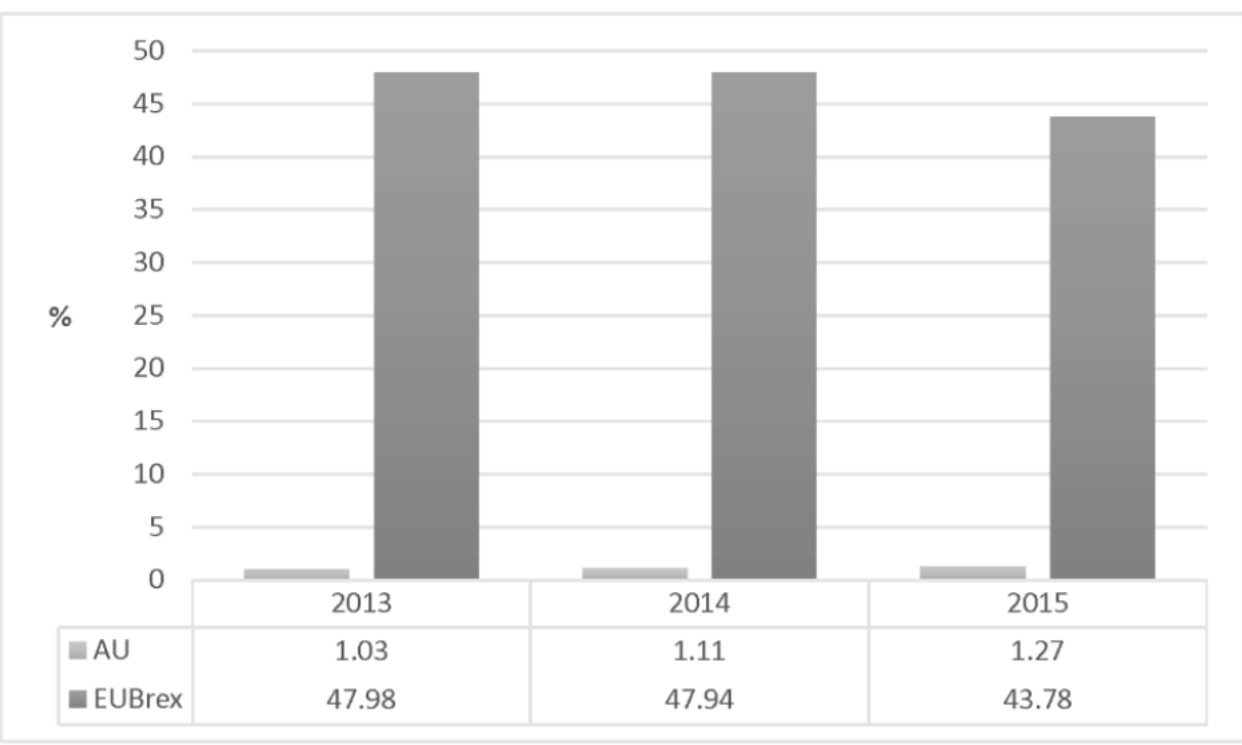

Notes: 1 . Geometric Mean $(\mathrm{AU})=1.13 \% ; 2$. Geometric Mean $($ EUBrex $)=46.53 \% ; 3$. FDI stock values based on inward directional principle

Source: OECD Stat Database and authors' calculations

Figure 10: Contribution to Total FDI Stock by Australia and EUBrex in UK (2013-15)

Consequently, due to the considerable scale of influence of the EUBrex MNCs on industrial production and service provision relations in the UK, it is likely that the future operational ability of the EUBrex MNCs in the UK market will take centre stage in post-Brexit negotiations.

Broadly, there are two possible outcomes of the post-Brexit negotiations in terms of the EUBrex MNC operations in the UK services market:

1) The UK and EU will finalise an agreement before the two-year term set by Article 50 of the EU Treaty, that is March 2019; or

2) Without a timely agreement, the UK and EU will revert by default to the nonpreferential multilateral system under the rules of the General Agreement on Trade in Services (GATS) by the World Trade Organization (WTO).

Australia's services sector is poised to lose from both outcomes, particularly without counteraction in terms of further investment cooperation, liberalisation and domestic reform.

Indeed, the first outcome will further embed Australia's services market subordination, whereas the second outcome is expected to indirectly hit the operations of Australian MNCs in the UK and those of foreign MNCs operating within the Australian services market. This is an area in need of more detailed investigation.

The second channel of capital investments on focus is portfolio investments (PI), understood in terms of equity and debt instruments that are tradable on financial markets.

The importance of financial markets to businesses relates to the influence these markets have in financing the consumption of consumers on the one hand, and the production of the businesses on the other hand. 
Accordingly, two measures calculate PI in the context of this paper:

a) Exposure of domestic held (Australian) portfolios to the UK and EUBrex financial markets that capture consumption implications; and

b) Exposure of the Australian financial market to the UK and EUBrex portfolios that gauge production implications.

Both measures are expressed as a percentage, i.e. the higher the value, the greater the exposure.

The exposure of Australian portfolios to the UK and EUBrex is determined by the percentage of Australian portfolios held in either market after making adjustments for home-bias, which is the tendency for investors to invest in a large amount of domestic financial assets, despite the purported benefits of international diversification.

Figure 11 below shows the exposure of Australian portfolios for the period 2007 to 2015, and indicates that exposure to both markets fell sharply around the start of the global financial crisis before increasing. A notable exception was the considerable reduction in exposure to the EUBrex financial market in 2014, which was subsequently followed by a record high exposure in 2015 .

Although average exposure for the period under investigation was 1.8 times higher in the EUBrex market (3.42 percent) to that of the UK market (1.89 percent), the average combined exposure was less than 6\%. The rise in exposure of Australian portfolios to the UK and EUBrex financial markets implies that market volatility created through a hard Brexit will have influence on Australian portfolios. However, given the low overall exposure of Australian portfolios to both the UK and EUBrex financial markets, a significant direct loss in overall wealth is likely to be limited.

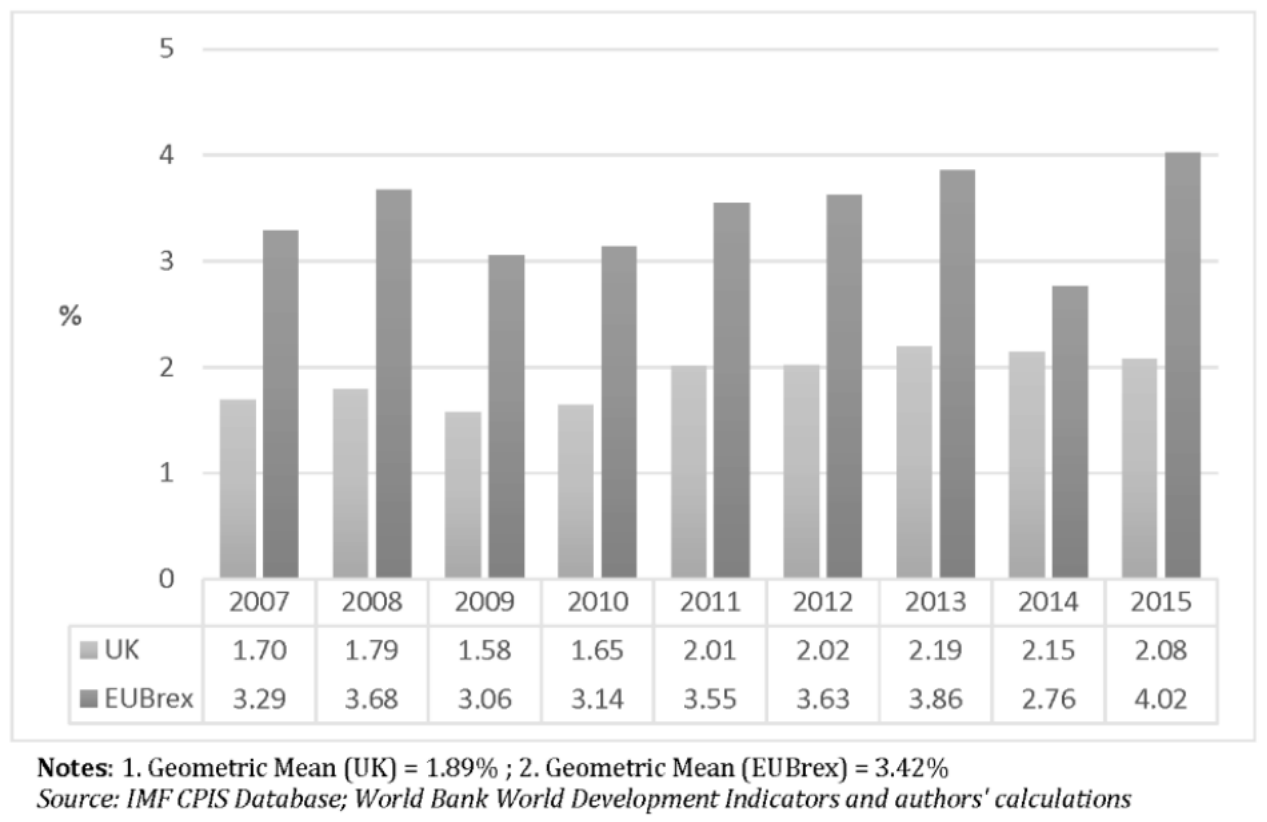

Figure 11: Exposure of Total Value of Australian Portfolios to UK and EUBrex financial markets (2007-15)

As the second measure of PI, the exposure of the Australian financial market to the UK and EUBrex portfolios is determined by the composition of the Australian financial 
market that was held in the UK and EUBrex portfolios from 2007 to 2015. Figure 12 below shows that the Australian exposure to both markets appears to follow a cyclical pattern, rising to the highest level around the start of the global financial crisis before falling and then rising once again. Notable exceptions were the UK in 2011 and the EUBrex in 2014.

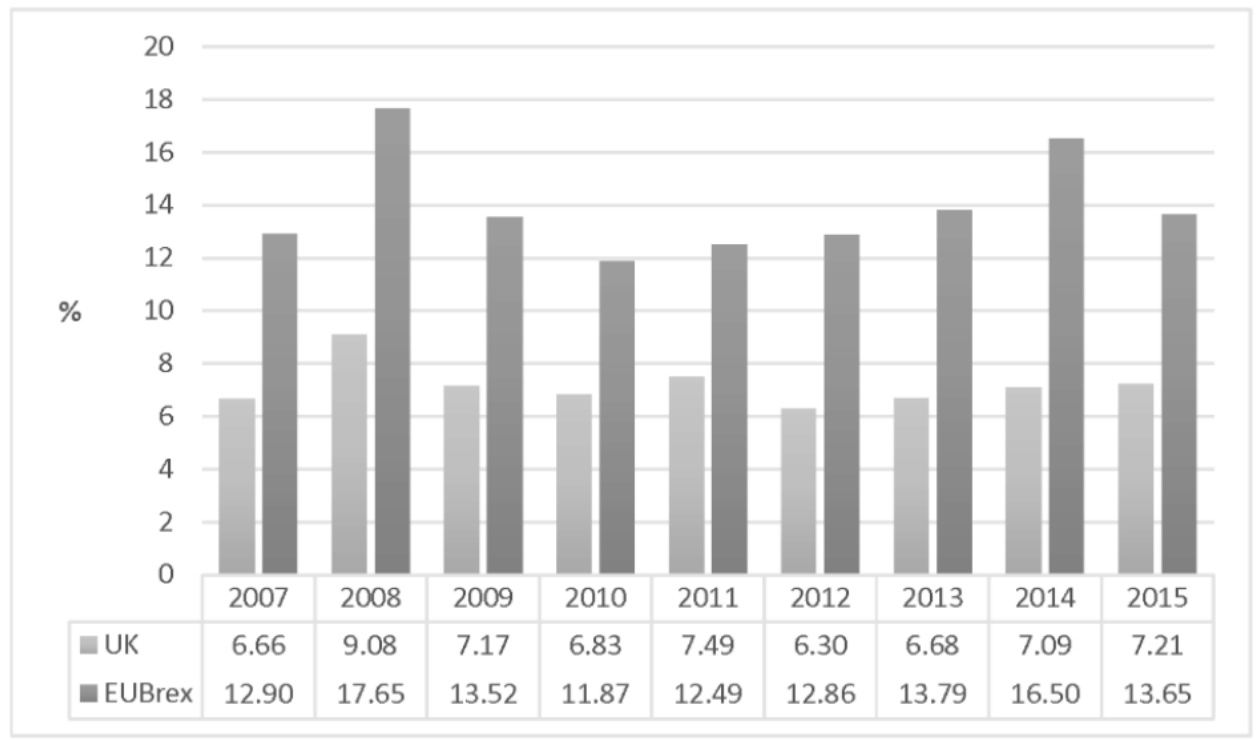

Notes: 1 . Geometric Mean (UK) $=7.13 \% ; 2$. Geometric Mean $($ EUBrex $)=13.81 \%$

Source: IMF CPIS Database; World Bank World Development Indicators and authors' calculations

Figure 12: Exposure of Australian Financial Market to UK and EUBrex Portfolios (2007-15)

The average exposure for the period under investigation was 1.9 times higher to the EUBrex portfolios (13.81 percent) than to the UK portfolios (7.13 percent).

The UK and EUBrex portfolios jointly account for approximately more than one-fifth of all asset holdings in the Australian financial market. These findings imply that the market volatility created by the hard Brexit will have a significant direct bearing on the Australian financial market and, given the high levels of home bias, a significant indirect bearing on Australian portfolios.

With the significant levels of exposure of the Australian financial market to the UK and EUBrex portfolios, another aspect that requires attention is the importance of London as a financial centre and as a gateway for the UK and EUBrex funds destined for the Australian financial market. The future positioning of London post-Brexit can thus have deeper long-term implications for patterns of financial flows and ultimately for Australia's financial solidity.

\section{Labour Movement}

The patterns of and implications for labour movement for Australia can be understood in terms of migrations flows to and from UK and EUBrex. Migrations flows are understood to have a positive influence on the economic growth of a nation as migrants increase the working-age population and improve overall productivity through their contributions to human development and technological progress (OECD, 2014). In order to assess how the pattern of migration to and from UK and EUBrex two broad measures were assessed between 2007 and 2014: share of total migrant flows and share of total worker flows. Both measures are represented by a percentage with an 
increasing value associated with increasing importance and will capture trends and implications for increases in working-age population in the host country over different time horizons. Accordingly, migrant flows can be linked to increases in the workingage population over longer horizons and worker flows to the working-age population over shorter horizons. Share of total worker flows further captures the trends of migrant flows and their implications for gains in productivity.

As demonstrated in figure 13 below, total migrant flows to Australia from the UK has been trending downwards since 2007 with notable upturns in 2012 and 2014. Total migrant flows to Australia from the UK have averaged above 12 percent of all migrants over the 2007-2014 period. This is contrasted with EUBrex total migrant flows which has maintained a shallow upward trend since 2007, averaging above 5 percent of all migrants to Australia. Joint migrant flows from the UK and EUBrex contributes nearly one-fifth of the longer term increase of the working age population attributed to migrant flows with UK contributing more than 2.2 times that of the EUBrex.

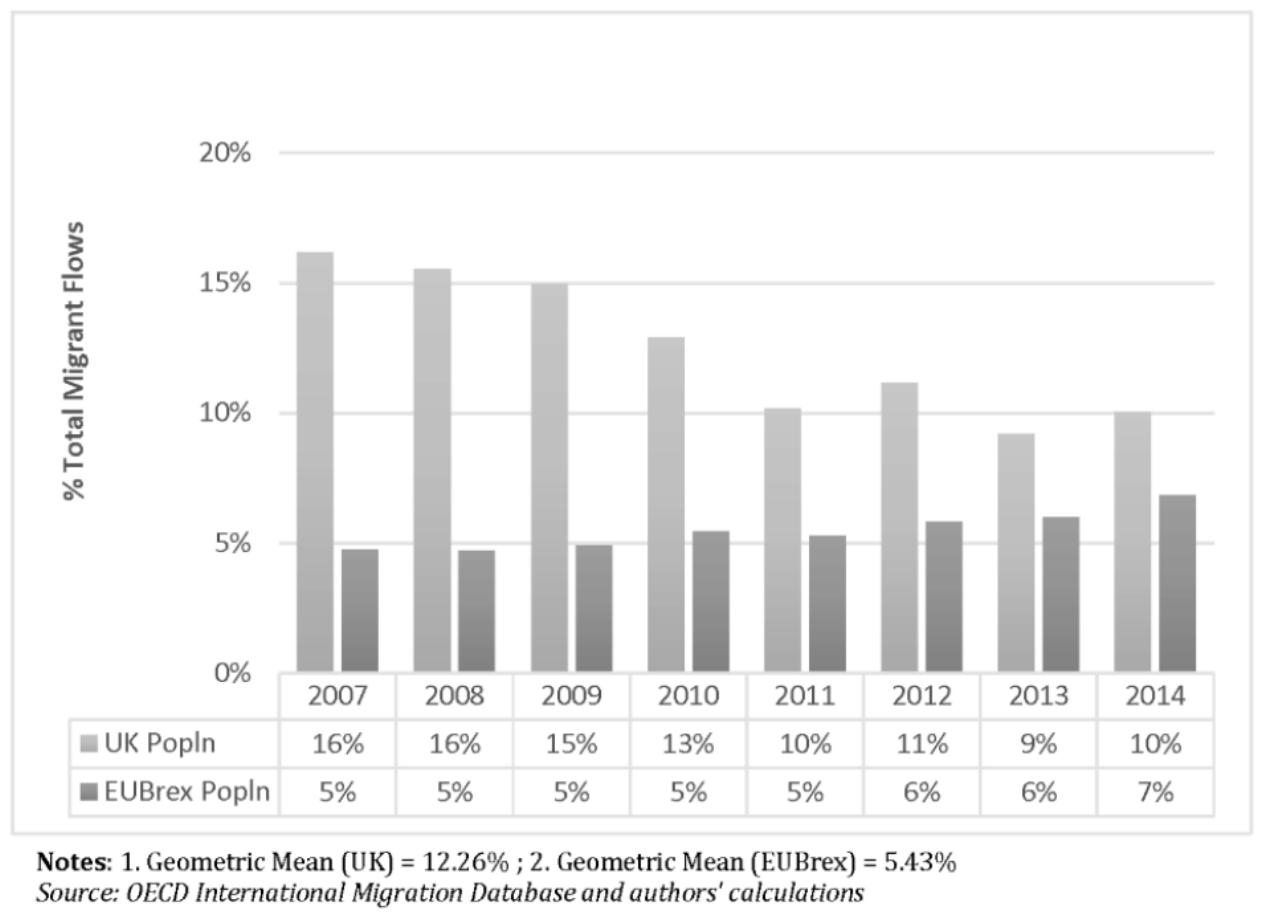

Figure 13: EUBrex and UK Populations in Australia (2007-2014)

Figure 14 below outlines the share of total worker flows to Australia from the UK and EUBrex from 2007 to 2014. UK worker flows to Australia appears to by cyclical following a downward trend from in 2007 with a minor peak in 2012. On average the UK has contributed more than 14 percent of the migrant worker flows to Australia over the period under observation. This is contrasted with the EUBrex migrant worker flows which has remained largely stable over the period of observation averaging more than 5.7 percent of migrant worker flows to Australia. Joint worker flows from the UK and EUBrex contributes no less than 15 percent of the shorter term increase in productivity attributed to the flows of migrant workers with UK contributing nearly than 2.5 times that of the EUBrex.

Under stable conditions the and given the trend in share of migrants and migrant worker, migration from EUBrex is expected to have greater contributions in longer 
horizons while contributions from UK are expected over shorter horizons. However, labour market changes and worker perceptions surrounding Brexit are unlikely to positively contribute to stable conditions. Given the lack of progress on Brexit negotiations, it is too early to predict the implications of Brexit for the direction and pattern of migrant flows from the UK and EUBrex.

In terms of the importance of Australian migrants to the UK and EUBrex, data limitations and irregularities limits to the analysis to Australian migrants to the UK for the period 2007 to 2012 - refer to figures 15 and 16 in the following page. Migrant flows from Australia to the UK (figure 16) follow a cyclical pattern, peaking in 2007, 2010 and 2012 and has averaged 3 percent of all migrant flows to the UK over the period. This is contrasted by the downward trend in worker flows from Australia to the UK (figure 16) which averaged 4 percent of all migrant workers to the UK over the period under analysis.

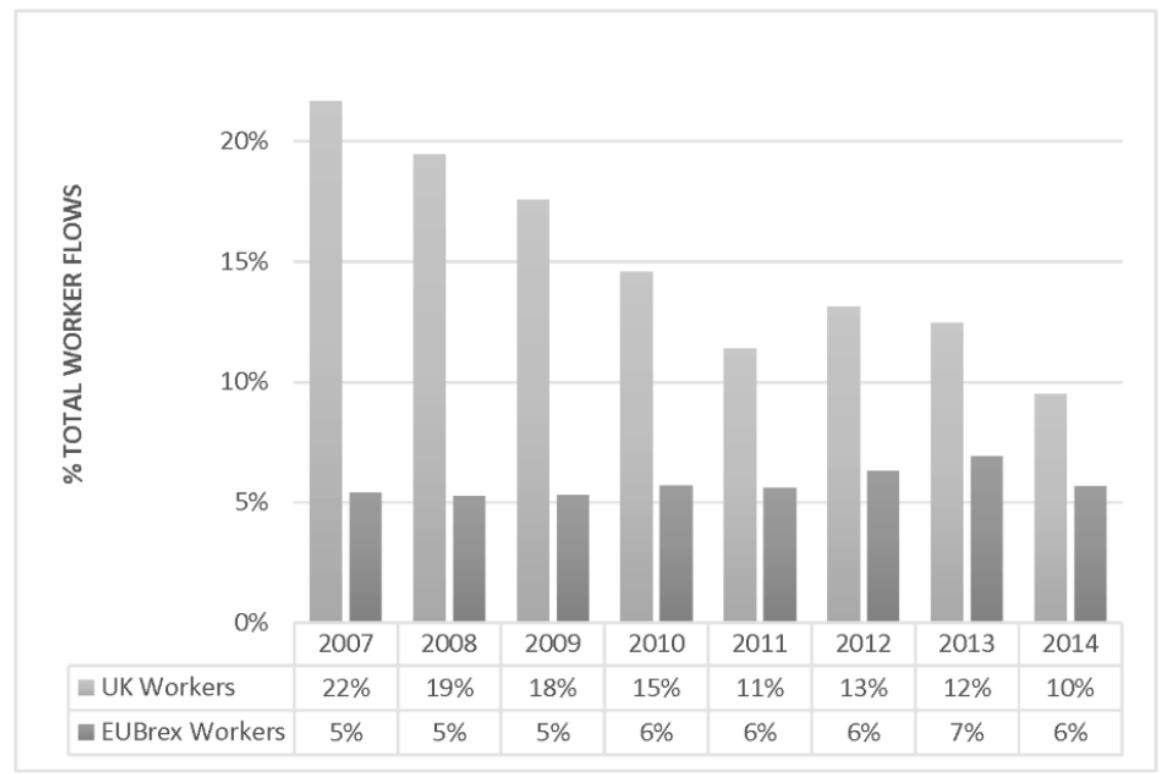

Notes: 1 . Geometric Mean $(\mathrm{UK})=14.46 \% ; 2$. Geometric Mean $($ EUBrex $)=5.74 \%$

Source: OECD International Migration Database and authors' calculations

Figure 14: EUBrex and UK Workers in Australia (2007-2014) 


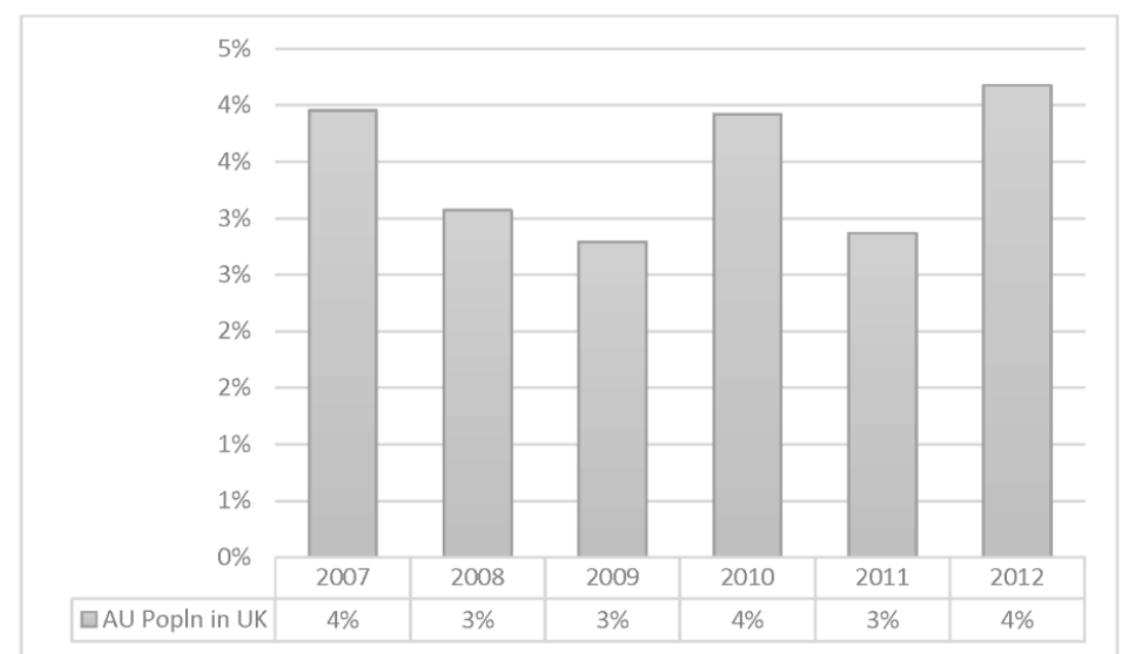

Notes: 1 . Geometric Mean $(\mathrm{AU})=3 \%$

Source: OECD International Migration Database and authors' calculations

Figure 15: Australian Population in the UK (2007-2012)

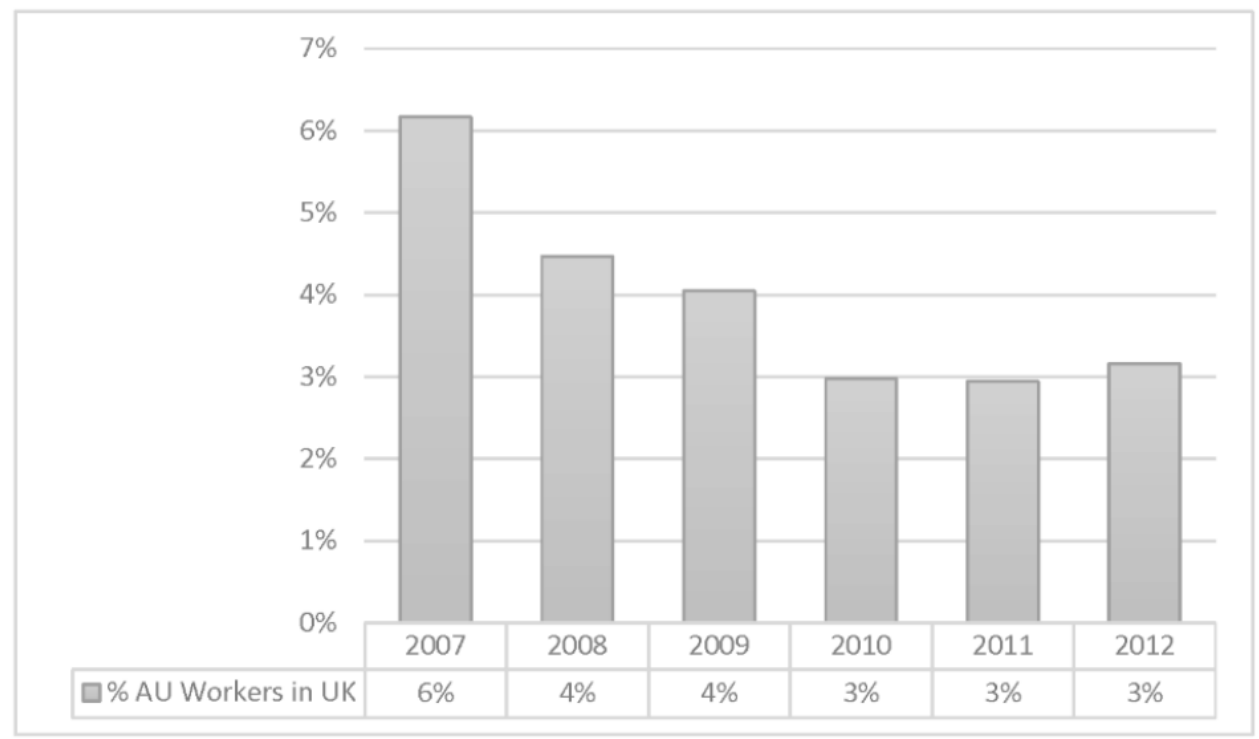

Notes: 1 . Geometric Mean $(\mathrm{AU})=4 \%$

Source: OECD International Migration Database and authors' calculations

Figure 16: Australian Workers in the UK (2007-2012)

Overall, Australian migrants and migrant workers are expected to make similar contributions to the working age population and productivity over short- and long horizons. However, Australian migrant and migrant worker flows remain a small component of worldwide migration flows to the UK. As with migrant flows to Australia, given the lack of progress on Brexit negotiations, it is too early to predict whether Australia can utilise the pattern of its migrant outflows flows to the UK to gain advantage for it citizens abroad.

\section{Implications and the Way Forward}

In February 2017, the UK's Prime Minister Theresa May presented to Parliament a white paper to explain that her government intends to leave the EU single market, 
pursue a new strategic partnership with the EU, and secure new trade agreements with other countries bilaterally and in wider groupings.

The clear indication for the so called "hard Brexit" line thus demarcates the possible avenues for Australia's separate trade and investment relations with the UK and EU. No formal step with the UK can be pursued until the conclusion of its withdrawal process from the EU, when the UK will finally become a separate customs entity, thus being entitled to negotiate international trade agreements.

Considering the present political climate and technical difficulties, it appears unlikely that the UK and EU will finalise an agreement before the two-year term set by Article 50 of the EU Treaty, or even before the advance of the Australia-EU free trade agreement.

Without a timely agreement, the UK and EU will revert by default to the nonpreferential multilateral system under the rules of the World Trade Organization (WTO). Essentially, this means that by March 2019 Australia, the UK and EU would all be levelled up within a multilateral regulatory framework of trade and investment relations.

This three-way levelling would eliminate the Australia-UK trade and investment subordination to the European single market at the regulatory level, however without discernible improvements in economic outcomes.

As things stand in projection of 2019, Australia's trade and investment relationship with the UK and the EU could take broadly four avenues of regulatory framework.

Based on the economic assessment described above, Australia's trade and investment diplomacy is likely to face the following four options of regulatory policy:

1. UK Unilateralism with EU Bilateralism - Concerting with the UK nonpreferential, non-reciprocal and non-binding trade and investment liberalisations in targeted sectors as soon as the Brexit process concludes, and reassess this strategy upon finalisation of the Australia-EU free trade agreement.

2. $U K$ and EU Bilateralism - Reciprocating preferential trade and investment concessions with the UK and the EU separately as soon as practicable in the post-2019 UK-EU arrangements.

3. Australia-UK-EU Trilateralism - Concurrently negotiating Australia-UK and Australia-EU preferential agreements for comprehensive integration with the post-2019 UK-EU agreement.

4. Long-term Multilateralism - Calling off trade agreements with both the UK and the EU to remain in the fold of the WTO system, and keep the 2019 status quo.

In line with the key points of the 2010 Australian Government's Productivity Commission Report on Bilateral and Regional Free Trade Agreements, this paper argues that any future preferential trade and investment arrangements with the UK and EUBrex should be negotiated in Australia's economic interests with a rigorous and transparent evidence-based approach. Negotiating with a rigorous and transparent evidence-based approach will require an independent body to conduct comprehensive pre-negotiation modelling based on realistic scenarios in comparison with alternative liberalisation options. 
Consequently, further trade negotiations with the UK and EUBrex should eventually enable a full and public assessment of the provisions actually agreed. Accordingly, in order to effectively commence, monitor and evaluate the future negotiating processes, and to ensure to have the cake and it too, Australia should not hasten to complete a bilateral free trade agreement (FTA) with the UK immediately after the Brexit process concludes, due to the highly uncertain geopolitical and economic climate that may unravel in the short term. Instead, Australia should consider to set up a nonpreferential and non-binding Economic Cooperation Forum with the UK (akin to the APEC for the Asia Pacific nations, an AUKEC so to speak) to be in place shortly after the conclusion of the Brexit process in March 2019. The so called AUKEC Forum should be designed to buy Australia time to see what happens in the UK and between the UK and EU in the medium term, at the same time providing a strong foundation to conclude a mutually beneficial FTA with the UK for the long term.

In the meantime, Australia should prioritise the conclusion of a comprehensive FTA with the EU to capitalise on the historically optimal relations discussed above, and use it to hedge its subsequent negotiating position with the UK, which is likely to be on a weaker competitive stance with the EU than Australia. Furthermore, Australia should avoid trilateral and multilateral options, as the end game should be at separate bilateral levels with both the EK and EU, in order to eventually achieve more favourable trading terms than the UK can achieve with the EU and vice versa. The overarching performance indicators of the negotiated provisions with both the UK and EUBrex should be to: 1) make Australia's economy more competitive in the European region; 2) strengthen Australia's geopolitical appeal to the emerging Asian powers; and 3) enable more self-reliant postures at a time of uncertain directions for the global security and economic policy of the US.

In conclusion, having considered the possible implications of Brexit on Australia's economic governance position with specific regard to the global value chains that rely on ease of trade and investments in the European single market, the aggregation of trade and investment data on market complementarity and financial exposure with the UK and the EU (minus the UK) indicates that it is in Australia's best interest to prioritise a preferential partnership with the EU over a new free trade agreement with the UK. Also considering the present political climate in Europe and technical regulatory difficulties, this paper ultimately argues that at this present time a decoupled approach of concerted unilateralism with the UK and preferential bilateralism with the EU is best placed to enhance Australia's role in Europe in the post-Brexit era.

\section{Bibliography}

Australian Government, Department of Foreign Affairs and Trade (2016), European Union Fact Sheet, retrieved from <https://dfat.gov.au/trade/resources/Documents/eu.pdf $>$

Australian Government, Department of Foreign Affairs and Trade (2016), United Kingdom Fact Sheet, retrieved from < https://dfat.gov.au/trade/resources/Documents/uk.pdf>

Australian Government, Productivity Commission, Bilateral and Regional Trade Agreements Research Report (Canberra, December 2010). 
Baldwin, R. (2016). The World Trade Organization and the future of multilateralism. The Journal of Economic Perspectives, 30(1), 95-115.

BBC News (2017) Brexit: What are the options? Retrieved from <http://www.bbc.com/news/uk-politics-37507129>

Bisley, N. (2007). Rethinking globalization. Palgrave Macmillan.

Her Majesty Government, The United Kingdom's exit from and new partnership with the European Union (London, February 2017).

Hussey, K., \& Kenyon, D. (2011). Regulatory divergences: a barrier to trade and a potential source of trade disputes. Australian Journal of International Affairs, 65(4), 381-393.

International Monetary Fund (2016), Consolidated Portfolio Investment Survey (CPIS) Database, retrieved from <http://data.imf.org/?sk=B981B4E3-4E58-467E9B90-9DEoC3367363>

Kenyon, D., \& Kunkel, J. (2005). Australia and the European Union in the World Trade Organisation: partners or adversaries? Australian Journal of International Affairs, 59(1), 55-69.

Kohl, T., \& Brouwer, A. E. (2014). The development of trade blocs in an era of globalisation. Environment and Planning A, 46(7), 1535-1553.

McKenzie, L. (2016). Market Power and Misunderstandings: The Case of EUAustralian Trade Diplomacy. Australian Journal of Politics \& History, 62(2), 219235 .

Murray, P., \& Benvenuti, A. (2014). EU-Australia Relations at Fifty: Reassessing a Troubled Relationship. Australian Journal of Politics \& History, 6o(3), 431-448.

OECD, see Organisation for Economic Co-operation and Development

Organisation for Economic Co-operation and Development (2014), Migration Policy Debates (May), retrieved from < https://www.oecd.org/migration/OECD\%20Migration\%20Policy\%20Debates\%20Numero\%202.pdf>

Organisation for Economic Co-operation and Development (2016), OECD EBOPS 2010/TiVA Database, retrieved from <https://stats.oecd.org/Index.aspx?DataSetCode=TISP_EBOPS2010>

Organisation for Economic Co-operation and Development (2017), OECD International Migration Database, retrieved from < http://www.oecdilibrary.org/social-issues-migration-health/data/oecd-international-migrationstatistics/international-migration-database_data-00342-en>

Poon, J. P. (1997). The cosmopolitanization of trade regions: global trends and implications, 1965-1990. Economic Geography, 73(4), 390-404. 
Poon, J. P., Thompson, E. R., \& Kelly, P. F. (2000). Myth of the triad? The geography of trade and investment 'blocs'. Transactions of the Institute of British Geographers, 25(4), 427-444.

Rimmer, S. H. (2016). Australian experiments in creative governance, regionalism, and plurilateralism. International Journal, 71(4), 630-650.

Sahu, P. K. (2016). Malaysia's Domestic Value Added Export: The Role of Governance and Strategic Policy Reforms. International Journal of Economics and Financial Issues, 6(4).

Scott, S (2004). The Political Interpretation of Multilateral Treaties, Brill Publishers

United Nations Conference on Trade and Development (2016), UNCTAD Stat

Database, retrieved from <http://unctadstat.unctad.org >

Villalta Puig, G. (2012). Trade and investment relations between the European Union and Australia: for a bilateral economic integration agreement. European Foreign Affairs Review, 17, 213.

WEF, see World Economic Forum

World Bank (2017), Word Development Indicators (WDI) - February 2017, retrieved from <http://data.worldbank.org/data-catalog/world-development-indicators>

World Economic Forum (2017), The world's 10 biggest economies in 2017, retrieved from <https://www.weforum.org/agenda/2017/o3/worlds-biggest-economies-in2017> 